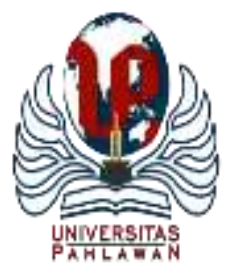

Edukatif : Jurnal Ilmu Pendidikan Volume 3 Nomor 6 Tahun 2021 Halm 3740 - 3747

EDUKATIF: JURNAL ILMU PENDIDIKAN

Research \& Learning in Education

https:/ledukatif.org/index.php/edukatif/index

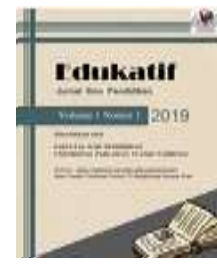

\title{
Perbandingan Cerita Rakyat Danau Toba dengan Cerita Rakyat Tsuru No Ongaeshi: Pendekatan Struktural
}

\author{
Yulia Kharisma Sarie ${ }^{1 凶}$, Sahlan Mutjaba², M. Januar Ibnu Adham ${ }^{3}$ \\ Universitas Singaperbangsa Karawang, Indonesia ${ }^{1,2,3}$ \\ E-mail : yulia.kharisma@ student.unsika.ac.id ${ }^{1}$, sahlan.mutjaba@ fkip.unsika.ac.id $^{2}$, \\ m.januar.ibnuadham@ fkip.unsika.ac.id ${ }^{3}$
}

\begin{abstract}
Abstrak
Penelitian ini bertujuan untuk menemukan perbandingan cerita rakyat Indonesia dan Jepang dengan menggunakan pendekatan struktural genetik. Cerita rakyat diperbandingkan terdiri dua cerita asal Indonesia dan Jepang yaitu Cerita Rakyat Danau Toba dan Cerita Rakyat Tsuru No Ongaeshi. Pendekatan struktural genetik menganalisis struktur cerita dan membandingkannya dengan menggunakan unsur instrinsik dan ekstrinsik pada masing-masing cerita . Hasilnya yaitu terdapat beberapa persamaan dan perbedaanya cerita dari Indonesia maupun Jepang contohnya alur dalam cerita menggunakan alur maju, latarnya sama-sama di rumah lalu, perbedaannya cerita rakyat danau toba mempunyai 2 tokoh pemuda bernama Toba dengan Ikan Mas, lalu cerita Tsuru No Ongaeshi mempunyai 3 tokoh yaitu kakek, nenek dan seekor burung soang yang menjalma sebagai putri yang dikutik. Lalu, beramanat tentang tidak boleh menyia-menyiakan kepercayaan orang lain serta mengingkari janji yang telah kita buat sedangkan cerita rakyat Tsuru No Ongaeshi tentang jangan meremehkan balas budi seseorang maka akan tahu akibatnya, seseorang yang telah berjanji akan berbalas budi namun dikecewakan tidak akan percaya lagi pada orang itu.
\end{abstract}

Kata Kunci: Pendekatan Struktural, Cerita Rakyat, Indonesia, Jepang

\section{Abstract}

This study aims to find a comparison of Indonesian and Japanese folklore using a genetic structural approach. The folklore is compared consisting of two stories from Indonesia and Japan, namely the Lake Toba Folklore and the Tsuru No Ongaeshi Folklore. The genetic structural approach analyzes the structure of the story and compares it by using intrinsic and extrinsic elements in each story. The result is that there are some similarities and differences in stories from Indonesia and Japan, for example, the plot in the story uses a forward plot, the setting is the same at home, the difference is that the Lake Toba folklore has 2 youth figures named Toba and Ikan Mas, then the Tsuru No Ongaeshi story has 3 The characters are grandfather, grandmother and a soang bird who transforms into a cursed princess. Then, the mandate is about not being able to waste other people's trust and breaking the promise we have made, while the Tsuru No Ongaeshi folklore about not underestimate someone's kindness will know the consequences, someone who has promised to return the favor but is disappointed will no longer believe in that person.

Keywords: Structural Approach, Folklore, Indonesia, Japan.

Copyright (c) 2021 Yulia Kharisma Sarie, Sahlan Mutjaba, M. Januar Ibnu Adham

$\triangle$ Corresponding author

Email : yulia.kharisma@student.unsika.ac.id

DOI : https://doi.org/10.31004/edukatif.v3i6.1260

ISSN 2656-8063 (Media Cetak)

ISSN 2656-8071 (Media Online) 


\section{PENDAHULUAN}

Cerita rakyat merupakan jenis cerita tradisional yang digunakan penuturnya untuk menjelaskan atau memahami dunia dan warisan lokal suatu daerah tertentu. Cerita rakyat dibuat untuk menyampaikan nilai-nilai terluhur dari suatu daerah pada generasi penerusnya. Cerita rakyat menurut wikipedia,2019 merupakan cerita yang berasal dari masyarakat indonesia yang telah diwarisi secara lisan. Cerita rakyat ini menjadi satu aset dari sikap, moral, perilaku dan nilai-nilai yang dimiliki oleh masyarakat indonesia yang terus berlanjut ke generasi seterusnya melalui tradisi tutur.

Pada penelitian Mifta Hardika Rahma Putri mahasiswa Program Studi Sastra Jepang Jurusan Bahasa dan Sastra Fakultas Ilmu Budaya Universitas Brawijaya yang berjudul "Studi Perbandingan Cerita Rakyat Indonesia " Danau Toba “ dengan Cerita Rakyat Jepang "Uo NyouBou " didalam penelitiannya Mifta hardika menganalisis perbandingan cerita rakyat Indonesia dengan Jepang dan pada penelitiannya tersebut perbedaan dalam analisis temuan budaya, latar belakang budaya antara suku Batak dengan Masyarakat Jepang, Motif kesamaan dalam cerita. Oleh karena itu, penelitian Mifta Hardika walaupun dikatakan relevan dengan penelitian ini namun terdapat perbedaan yang cukup signifikan yaitu pada penelitian Mifta Hardika Rahma Putri tidak ditemukan atau unsur Ekstrinsiknya berbeda dengan penelitian ini karena menggunakan unsur instrinsik dan ekstrinsik di dalam analisis perbandingan cerita rakyat Indonesia dengan Jepang. Merujuk kata ekstrinsik sebelumnya maka menurut (Nurgiyantoro, 2010: 23) menyatakan unsur luar dalam karya sastra yang memiliki sifat tidak langsung mempengaruhi bangunan atau bagian terpenting karya sastra.

Selanjutnya, pada penelitian Nindi Heranda Rinaldi mahasiswa Program Studi Sastra Jepang Departemen Sastra Jepang Fakultas Ilmu Budaya Universitas Sumatera Utara Medan 2016 "Analisis Perbandingan Cerita Rakyat Tanabata dan Jaka Tarub dilihat berdasarkan Pendekatan Struktural " didalam penelitian Nindi Heranda menganalisis Perbandingan Cerita rakyat " Tanabata " dari Jepang dan Cerita Rakyat "Joko Tarub " dari Indonesia. Pada penelitiannya tersebut Nindi Heranda hanya menemukan dan mendeskripsikan hasil temuannya tidak menjelaskannya dengan tabel dan rinci hanya menjelaskan saja.

Berdasarkan pemaparan yang berupa penjelasan-penjelasan diatas maka dapat dikatakan penelitian ini yang peneliti lakukan berbeda dengan penelitian-penelitian relevan sebelumnya yang sudah dilakukan oleh peneliti atau dapat dikatakan juga penelitian ini tidak meniru atau Copy Paste dari karya peneliti lain. Oleh karena itu, berdasarkan penjelasan atau latar belakang diatas maka peneliti memilih judul yaitu "Perbandingan Cerita Rakyat Danau Toba dengan Cerita Rakyat Tsuru No Ongaeshi: Pendekatan Struktural".

Dalam masyrakat tuturnya, cerita rakyat mempresentasikan sikap, moral, nilai-nilai dan angan-angan kelompok, alat pendidikan, alat pengesahan dan lembaga kebudayaan. Cerita rakyat tidak hanya berfungsi sebagai alat hiburan, pengisi waktu senggang atau lainnya, tapi cerita rakyat adalah bukti murni foklor lisan yang ada di indonesia. Sebagaimana dikatakan Lilik dalam (Danandjaja, 1997) bahwa cerita rakyat merupakan bagian dari folklor lisan yang masih murni. Sedangkan foklor itu sendiri merupakan kebudayaan suatu kelompok dalam bentuk apa saja.

Penelitian ini berfokus pada perbedaan dan persamaan cerita, perbandingan unsur instrinsik dan ekstrinsik pada cerita rakyat tersebut. Penelitian ini berbeda dengan penelitian yang sebelum-sebelumnya dikarenakan peneliti menganalisis perbandingan cerita rakyat dari Indonesia dengan Jepang, walaupun banyak penelitian dari sebelumnya meneliti hal tersebut. Namun, peneliti menganalisis perbedaan dan persamaan dari kedua cerita ini dari unsur instrinsik dan ekstrinsiknya. Peneliti tidak menganalisis dari unsur kebudayaannya hanya menganalisis nilai-nilai yang terkandung pada cerita karya sastranya.

Analisis Gap dilakukan untuk mengetahui kesenjangan yang terjadi antara teori yang dipakai dengan penelitian yang dikaji. Menurut (Nurgiyantoro, 2010: 24) pembagian unsur instrinsik struktur karya sastra yang tergolong tradisional adalah pembagian unsur bentuk dan isi sebuah pembagian dikhotomis atau suatu aspek teologis menyatakan bahwa diri manusia dapat dibedakan menjadi dua aspek, yakni jiwa yang bersifat 
3742 Perbandingan Cerita Rakyat Danau Toba dengan Cerita Rakyat Tsuru No Ongaeshi: Pendekatan Struktural - Yulia Kharisma Sarie, Sahlan Mutjaba, M. Januar Ibnu Adham

DOI: https://doi.org/10.31004/edukatif.v3i6.1260

rohani dan tubuh yang bersifat jasmani. Pada penelitian ini peneliti menemukan perbedaan yang cukup signifikan bahwasanya peneliti hanya menganalisis karya sastra dalam cerita rakyat tidak menyangkut pautkan tentang diri manusia.

Tujuan dari penelitian ini ialah untuk menjelaskan dan mendeskripsikan tema, tokoh, alur, latar, dan amanat dan untuk mengetahui persamaan dan perbedaan pada unsur instrinsik dan ekstrinsik pada kedua cerita rakyat yang berjudul Danau Toba dan Tsuru No Ongaeshi.

\section{METODE PENELITIAN}

Penelitian yang berjudul Perbandingan Cerita Rakyat Danau Toba dengan Cerita Rakyat Tsuru No Ongaeshi merupakan penelitian kualitatif sedangkan pendekatan yang digunakan adalah pendekatan struktural genetik. Pendekatan menurut (Endraswara, 2013: 50) merupakan bagaimana data diungkap dan bagaimana analisis data diproses, dari sudut pandang apa data penelitian hendak diolah hingga memperoleh kesimpulan yang handal. Oleh karena itu pendekatan struktural genetik dipilih untuk dapat mendiskripsikan unsur intrinsik, yakni tema, alur, tokoh, latar, amanat, sudut pandang, dan gaya bahasa dalam Cerita Rakyat Legenda Danau Toba dan Cerita Rakyat Tsuru No Ongaeshi.

Metode merupakan cara-cara, strategi untuk memahami realitas, Langkah-langkah sistematis untuk menyederhanakan masalah sehingga lebih mudah untuk dipecahkan dan dipahami (Ratna, 2004: 34). Pada penelitian ini penulis menggunakan metode penelitian deskriptif dengan tujuan untuk mendiskripsikan dan memberikan pemahaman dan penjelasan khususnya terhadap perbedaan kebudayaan yang terdapat pada kedua cerita.

Ada delapan jenis penelitian kualitatif yakni etnografi, studi kasus, studi dokumen atau teks, observasi atau pengamatan alami, wawancara terpusat, fenomenologi, grounded theory, studi sejarah (Sujarweni, 2019: 21). Pada penelitian ini peneliti memilih atau menggunakan jenis studi dokumen atau teks karena efektif atau efisien dengan penelitian ini. Untuk tahap atau proses mengumpulkan data-data nya peneliti menggunakan teknik pengumpulan baca dan catat yaitu peneliti membaca atau melihat data-data yang sudah dikumpulkan sebelumnya lalu peneliti mencatat semua data-data yang telah ditemukan atau didapatkan setelah membaca atau melihat data-data pada sebelumnya.

Studi dokumen atau teks merupakan kajian dari bahan dokumenter yang tertulis bisa berupa buku teks, surat kabar, majalah, surat-surat, film, catatan harian, naskah, artikel, dan sejenisnya (Sujarweni, 2019: 23).

Subjek penelitian ini tentang cerita rakyat Danau Toba dengan cerita rakyat Tsuru no Ongaeshi. Menentukan subjek pandangan bisa dinyatakan sejalan apabila benda atau orang dapat melekat. Subjek sastra bandingan berkaitan dengan karya sastra yang dibandingkan, berbentuk novel, cerpen, puisi, karya siapa dan sebagainya. Subjek juga berhubungan dengan tahun penciptaan karya, karya saduran, terjemahan, dan karya asli. Objek adalah " bahan penelitian " yang menjadi fokus sastra bandingan. Objek berkaitan dengan muatan apa yang terdapat dalam sastra, yang dominan dan layak dibandingkan (Endraswara, 2013: 163).

Pada penyajian data ini, data yang didapatkan akan dihubungkan dengan teori-teori relevan seputar pendekatan Struktural genetik yang nantinya akan menjawab semua permasalahan yang ingin dipecahkan. Lalu penyimpulan harus dapat menjawab semua permasalahan yang diangkat dalam penelitian tersebut.

\section{HASIL DAN PEMBAHASAN PENELITIAN}

Cerita rakyat Danau Toba diambil dari cerita karya Rose Mini yang dimana bercerita tentang seorang pemuda yang bernama Toba yang menikah dengan ikan mas namun mengikari janji dari sang ikan emas tersebut sedangkan cerita rakyat Tsuru No Ongaeshi cerita rakyat dari masyarakat Jepang diambil dari Situs 
web Jepang bernama Kyoshi, cerita yang menceritakan sosok bangau yang berbalas budi kepada kedua kakek nenek yang menolongnya.

Pada bagian ini peneliti akan menjabarkan atau mendeskripsikan hasil dan pembahasan secara rinci dari data-data yang sudah dianalisis oleh peneliti yang sesuai dengan judul penelitian ini yaitu "Perbandingan Cerita Rakyat Danau Toba dengan Cerita Rakyat Tsuru No Ongaeshi: Pendekatan Struktural" yakni sebagai berikut :

Tabel 1. Perbandingan Cerita Rakyat Danau Toba Dengan Cerita Rakyat Tsuru No Ongaeshi

\begin{tabular}{llll}
\hline Perbedaan dan & Cerita Rakyat Danau Toba & Cerita Rakyat & Tsuru No \\
Persamaan antara Danau & Ongaeshi & & \\
Toba dengan Tsuru No & &
\end{tabular}

Ongaeshi

1. Tema Pentingnya memegang janji yang telah Balas budi yang berakhir dibuat dikecewakan

2. Tokoh Terdapat satu tokoh utama yaitu Toba dan dua tokoh pembantu.

Terdapat tiga tokoh yaitu suami dan istri yang sudah tua serta seekor bangau

3. Alur Alur maju karena penulis menceritakan Alur maju karena penulis dari Awal hingga Akhir dengan Runtut dan jelas menceritakan dari Awal hingga Akhir dengan Runtut dan jelas

4. Latar Rumah. Terdapat pada kutipan "sesampainya ia di rumah, ia tidak jadi memakan ikan itu karena indahnya. Ia lebih memilih untuk memeliharanya. Ditempatkannya ikan itu di sebuah wadah besar dan diberinya makan “

Latar waktu Siang hari terdapat pada kutipan "
keesokan harinya, seperti biasa ia pergi bertani. Siang hari ia pulang sebentar ke rumah untuk makan siang “ Rumah. Terdapat Pada kutipan ““” salju turun sangat lebat, seseorang gadis cantik datang ke rumah ke pasangan tua ".

Siang hari dan malam hari terdapat di kutipan " Pada hari yang bersalju di musim dingin, sang suami pergi ke kota untuk menjual kayu bakar " dan pada kutipan yang menggambarkan malam hari sebagai berikut: " malam harinya, salju turun sangat lebat, seorang gadis cantik datang ke rumah pasangan tua".

\begin{tabular}{|c|c|c|}
\hline Latar suasana & $\begin{array}{l}\text { cerita rakyat ini beragam dikarenakan } \\
\text { konflik-konflik yang muncul beragam. } \\
\text { Terdapat pada kutipan "ia bertanya kepada } \\
\text { anaknya dan marahlah ketika tahu } \\
\text { anaknya memakan makanan itu. Ia } \\
\text { menampar pipi anaknya sambil berkata " } \\
\text { memang betullah kau ini anaknya ikan ". } \\
\text { Sang anak berlari pulang sambil menangis } \\
\text { lalu mengadu pada ibunya " }\end{array}$ & \begin{tabular}{llr} 
cerita yang & \multicolumn{2}{c}{ menggambarkan } \\
suasana cemas. Terdapat pada \\
kutipan " mereka tidak bisa \\
menutupi rasa penasaran yang \\
menyelimuti mereka sehingga \\
sang istri mengintip ke dalam \\
ruangan ".
\end{tabular} \\
\hline 5. Amanat & $\begin{array}{l}\text { Tidak boleh menyia-menyiakan } \\
\text { kepercayaan orang lain serta mengingkari } \\
\text { janji yang telah kita buat. }\end{array}$ & $\begin{array}{l}\text { Jangan meremehkan balas budi } \\
\text { seseorang maka akan tahu } \\
\text { akibatnya, seseorang yang telah } \\
\text { berjanji akan berbalas budi namun } \\
\text { dikecewakan tidak akan percaya }\end{array}$ \\
\hline
\end{tabular}


lagi pada orang itu.

$\begin{array}{lll}\text { 6. Sudut pandang } & \text { Sudut pandang orang ketiga. Sudut } & \text { Sudut pandang orang pertama } \\ \text { pandang ini menggunakn kata ganti } & \text { pelaku utama karena dalam } \\ \text { orang ketiga seperti dia,ia dan nama orang } & \text { penceritan cerita rakyat penulis } \\ \text { yang dijadikan sebagai titik berat cerita. } & \text { menggunakan kata "saya". Tokoh } \\ & & \text { "saya" dalam cerita rakyat ini } \\ & & \text { diceritakan paling dominan } \\ & \text { sehingga si tokoh "saya" dapat } \\ & \text { dikatakan sebagai tokoh atau } \\ & \text { pelaku utama. Berikut pada } \\ & \text { kutipan: saya ingin menenun } \\ & \text { kain, tolong belikan saya benang ". }\end{array}$

Temuan yang kedua adalah mengenai unsur ekstrinsik yang ada di dalam cerita rakyat Danau Toba dan Tsuru No Ongaeshi, yaitu sebagai berikut:

\section{Latar belakang tempat tinggal}

Lingkungan tempat tinggal pengarang biasanya juga akan mempengaruhi penciptaan sebuah cerita, begitupun dengan cerita rakyat Danau Toba dan Tsuru No Hanashi ini. Pada cerita Danau Toba, latar lokasi nya yaitu terletak di Provinsi Sumatra Utara dan masuk di beberapa Kabupaten, yakni Kabupaten Samosir, Toba Samosir, Simalungan, Karo, Tapanuli Utara, Humbang Hasundutan, dan Dairi. Dengan mayoritas masyarakatnya berasal dari suku Batak. Sedangkan pada cerita rakyat Tsuru No Hanashi, berlatar di Negara Jepang tetapi tidak dijelaskan secara lebih rinci mengenai lokasi persisnya.

\section{Latar belakang sosial budaya}

Lokasi cerita rakyat Danau Toba termasuk ke dalam Suku Batak yang mendiami sekitaran pegunungan Sumatera Utara dengan kondisi alam yang baik dan subur sehingga banyak penduduknya memilih berprofesi sebagai petani, dan ketika pada musim-musim tertentu, penduduk di sekitar pulau Samosir akan menangkap ikan dan menjadikannya sebagai profesi sementaranya. Sejalan dengan lokasi tempat tinggalnya, kebanyakan orang Batak biasanya memiliki watak tegas dan keras dalam pendiriannya hingga tak jarang mereka dikatakan sebagai suku yang kasar, tetapi di balik itu mereka memiliki etos bekerja keras dan disipilin. Sedangkan dalam kebudayaan Jepang, mereka mempunyai empat musim, yaitu musim semi, musim gugur, musim panas, dan musim dingin. Oleh karena itu, orang Jepang biasanya bersifat gigih dan pantang menyerah. Sejak kecil orang Jepang sudah diajarkan untuk bekerja keras dalam mendapatkan keinginannya.

Lalu ada juga perlambangan dari ikan mas pada kebudayaan Batak dan perlambangan bangau pada budaya Jepang. Bagi masyarakat Batak, ikan mas sering disajikan dalam setiap adat Batak mulai dari kelahiran, pernikahan hingga kematian. Mereka memaknai nya sebagai perwujudan atau simbol berkat kehidupan. Filosofinya ikan mas adalah hidup rukun Bersama-sama seperti ikan mas yang berenang Bersamasama tanpa saling bertubrukan.

Lain hal nya dengan kepercayaan Jepang terhadap bangau. Di Jepang, burung bangau dianggap sebagai burung yang suci dengan banyaknya cerita kepahlawan dongeng dan legenda tentang burung bangau. Bagi orang Jepang, bangau melambangkan umur penjang dan kemakmuran, dan burung bangau juga melambangkan harapan. Orang Jepang banyak yang meyakini bahwa jika membuat seribu derek kertas senbazuru, segala keinginan akan terkabul dan bahkan penyakit yang serius bisa sembuh. 


\section{Latar belakang religi (agama).}

Batak memiliki banyak agama dan kepercayaan, seperti agama Kristen, Islam, dan Katolik. Tetapi sebelum masyarakat Batak juga mempunyai agama asli mereka sendiri yang disebut agama Malim. Agama Malim atau juga sering disebut Ugamo Malim adalah agama lokal/ asli yang dianut oleh masyarakat yang berada di sekitaran Kabupaten Toba Samosir, Tapanuli Utara, juga di daerah lain seperti Kabupaten Simalungan, Kabupaten Dairi, dan Kabupaten Tapanuli Tengah. Ugamo Malin memiliki jumlah penganut antara 5.000 sampai 11.000 jiwa, terbilang menoritas memang jika dibandingkan dengan jumlah penduduk batak.

Sedangkan mayoritas warga Jepang menganut agama Shinto yang sejarah harfiah bermakna jalan/jalut dewa. Agama Shinto merupakan agama asli yang berasal dari Jepang, maka tak heran bila dari 290 juta penduduk Jepang ada 107 juta orang yang menganut agama ini. Agama Shinto terbilang unik karena merupakan perpaduan antara paham serba jiwa (animisme) dengan pemujaan terhadap gejala-gejala alam mempercayai bahwasanya semua benda baik yang hidup maupun yang mati dianggap memiliki ruh atau spirit, bahkan kadang-kadang dianggap pula berkemampuan untuk bicara, semua ruh atau spirit itu dianggap memiliki kekuasaan yang berpengaruh terhadap kehidupan mereka (penganut Shinto), daya-daya kekuasaan mereka tersebut mereka puja dan disebut dengan "Kami” Selain mempercayai adanya dewa-dewa, masyarakat Jepang mempercayai adanya kekuatan gaib yang mencelakakan yakni hantu atau roh-roh jahat yang disebut "Aragami".

\section{Latar belakang ekonomi}

Latar belakang ekonomi yang terdapat dalam cerita rakyat Danau Toba dan cerita rakyat Tsuru no Ongaeshi memiliki perbedaan yang signifikan. Dalam cerita rakyat Danau Toba penulis mennyajikan cerita rakyat sesuai legenda ya di kepulauan danau toba bisa dikatakan penulis menceritakan perekenomian Toba yang sederhana mencari sesuap nasi dengan bertani dan memancing. Berbeda dengan cerita rakyat Tsuru no Ongaeshi, di dalam cerita pasangan tua yang berkehidupan berkecupan dari menjual kayu bakar ke kota berubah menjadi menjual kain tenun yang dibuat oleh sang bangau.

\section{Latar belakang pendidikan}

Latar belakang pendidikan di kedua cerita rakyat ini tidak mempunyai latar belakang pendidikan dikarenakan pengarang tidak menjelaskan secara spesifik cerita rakyat hanya membahas inti-inti dalam cerita rakyat. Baik di cerita rakyat danau toba atau Tsuru no Ongaeshi sama tidak ada bedanya tidak mempunyai latar belakang pendidikan.

\section{Latar belakang penulis}

Latar belakang penulis dalam kedua cerita rakyat ini anonim atau tidak ada identitas dalam pengarang. Cerita rakyat Danau Toba berasal dari Indonesia dan cerita rakyat Tsuru no Ongaeshi berasal dari jepang. Yang pastinya anonim karena cerita rakyat turun temurun dari masyarakat satu ke masyarakat lainnya. Dikembangkan dengan versi yang berbeda setiap tahunnya. Namun, cerita rakyat Danau Toba telah diapdatasi oleh Pengarang Yaitu Rose Mini dalam bukunya menceritakan cerita rakyat Danau Toba sedangkan cerita Rakyat Tsuru No Ongaeshi pun telah diperbaharui menjadi cerita yang berkembang.

Dalam hasil pembahasan yang peneliti jelaskan diatas ada pertentang teori dengan hasil penelitian Ade Karlina Jada Mahasiswa Program Studi Sastra Jepang Fakultas Ilmu Budaya Universitas Diponegoro 2016 “ Perbandingan Cerita Rakyat Jepang Yuki-Onna dan Cerita Rakyat Indonesia Dewi Nawang Wulan" Pada penelitiannya menggunakan teori pragmatik yang sebagaimana menurut Wibowo (2018:11) merupakan bagian ilmu bahasa yang menyoroti tentang makna Language In Use ' bahasa dalam penggunaanya' yang terikat oleh konteks. Berbeda dengan peneliti analisis menggunakan teori pendekatan struktural. 
Berdasarkan penelitian diatas maka dapat terlihat persamaan dan perbedaan dari kedua cerita rakyat tersebut dari unsur instrinsik dan unsur ekstrinsik. Oleh karena itu, peneliti telah menganalisis Tema, Tokoh, Alur, Latar, Amanat, dan sudut pandang pada kedua cerita tersebut.

\section{KESIMPULAN}

Berdasarkan penjelasan-penjelasan yang sudah dipaparkan diatas maka peneliti memiliki kesimpulan yang sesuai dengan yang sudah dijelaskan diatas atau sebelumnya yaitu: Cerita rakyat merupakan jenis cerita tradisional yang digunakan penuturnya untuk menjelaskan atau memahami dunia dan warisan lokal suatu daerah tertentu. Cerita rakyat dibuat untuk menyampaikan nilai-nilai terluhur dari suatu daerah pada generasi penerusnya. Terdapat unsur instrinsik dan ekstrinsik, unsur intrinsik yaitu: 1) Tema, 2) Tokoh, 3) Alur, 4) Latar, 5) Amanat dan 6) Sudut Pandang. Berdasarkan hasil dan pembahasan penelitian ini dapat dikatakan telah tercapai tujuan dari penelitian ini yaitu untuk mengetahui atau mendeskripsikan perbedaan dan persamaan cerita rakyat menggunakan unsur instrinsik dan ekstrinsik pada Perbandingan Cerita Rakyat Danau Toba dengan Cerita Rakyat Tsuru No Ongaeshi. Hasil penelitian ini diharapkan atau direkomendasikan untuk digunakan sebagai referensi atau acuan oleh para peneliti lain yang hendak melakukan penelitian mengenai perbandingan cerita rakyat Indonesia dengan Jepang dan juga hasil penelitian ini diharapkan atau direkomendasikan untuk menjadi bahan bacaan yang menambah wawasan pengetahuan masyarakat atau orang lain.

\section{UCAPAN TERIMA KASIH}

Peneliti panjatkan puji dan syukur kehadirat Allah SWT yang senantiasa memberikan rahmat dan hidayah-Nya kepada peneliti dan juga peneliti mengucapkan terima kasih kepada kedua orang tua, dosen pembimbing dan idol group jkt48 yang sudah memberikan motivasi, doa dan semangat sehingga peneliti dapat menyelesaikan penelitian ini.

\section{DAFTAR PUSTAKA}

Aminudin. (2002). Pengantar Apresiasi Karya Sastra. Sinar Baru.

Anjarwati, P. (2017). Perbandingan Dongeng Jepang Komebuki Awabuki Dengan Dongeng Indonesia Bawang Merah Bawang Putih. Universitas Diponegoro.

Ariefa, N. A. (2018). Perempuan Pada Cerita Rakyat Jepang Dan Indonesia: Analisis Komparatif Dengan Pendekatan Feminisme. Jurnal Al-Azhar Indonesia Seri Humaniora, 4(3).

Balas Budi Burung Bangau (Tsuru No Ongeshi). (2020). In Ensiklopedia Bebas.

Cerita Rakyat Jepang. (2007). In Ensiklopedia Bebas.

Danandjaja, J. (1997). Folklor Jepang Dilihat Dari Kacamata Indonesia. Pustaka Utama Grafiti.

Endraswara, S. (2013). Metodologi Penelitian Sastra. Caps (Center Of Academic Publishing Service).

Fatimah, F. N. (N.D.). Cerita Rakyat Dewi Sritanjung Sebagai Upaya Mewujudkan Pendidikan Karakter Berbasis Nilai Kearifan Lokal. Universitas Sebelas Maret.

Hidayat, W. Al. (2019). Struktur Dan Fungsi Cerita Rakyat Benayuk Versi Desa Sepala Dalung Kabupatentana Tidung: Kajian Strukturalisme Naratologi . Universitas Mulawarman.

Jada, A. K. (2016). Perbandingan Cerita Rakyat Jepang Yuki-Onna Dan Cerita Rakyat Indonesia Dewi Nawang Wulan Analisis Nilai-Nliai Moral. Universitas Diponegoro. 
3747 Perbandingan Cerita Rakyat Danau Toba dengan Cerita Rakyat Tsuru No Ongaeshi: Pendekatan Struktural - Yulia Kharisma Sarie, Sahlan Mutjaba, M. Januar Ibnu Adham

DOI: https://doi.org/10.31004/edukatif.v3i6.1260

Kuyoshi. (2021). Tsuru No Ongeshi.

Ningsih, N. H. (2016). Analisis Perbandingan Cerita Rakyat Tanabata Dan Jaka Tarub Dilihat Berdasarkan Pendekatan Struktrural. Departemen Sastra Jepang Universitas Sumatera Utara.

Nurgiyantoro. (2010). Teori Pengkajian Fiksi. Gadjah Mada University Press.

Putri, M. H. R. (2013). Studi Perbandingan Cerita Rakyat Indonesia "Danau Toba” Dengan Cerita Rakyat Jepang "Uo Nyoubou." Universitas Brawijaya.

Ratna, K. (2004). Teori, Metode, Dan Teknik Penelitian Sastra. Pustaka Pelajar.

Riansyah. (2021). Perbandingan Cerita Rakyat "Terjadinya Bukit Tangkiling" Dan "Tangkuban Perahu": Sebuuah Pendekatan Struktural. Balai Bahasa Provinsi Kalimantan Tengah.

Rose, M. (2018). Cerita Rakyat Danau Toba. Indocamp.

Rosidi, A. (2013). Ikhtisar Sejarah Sastra Indonesia. Pustaka Jaya.

Sari, I. A. L. (2020). Kappa: Makhluk Mitologis Penjaga Sungai Dalam Cerita Rakyat Jepang . Universitas Udayana.

Sudarmanto, B. A. (2018). Paradigma Kultural Masyarakat Durkheimian Dalam Cerita Rakyat Langkuse Dan Putri Rambut Putih (Sebuah Pendekatan Sosiologi Sastra). Universitas Pgri Palembang.

Sujarweni, V. W. (2019). Metodologi Penelitian. Pustaka Baru Press.

Wahyuni, L. (2019). Motif Cerita Rakyat Malin Kundang Sebagai Sarana Penjaga Integritas Sosial Masyarakat Asean. Universitas Brawijaya.

Wibowo, S. E. (2018). Etnopragmatik. Cv. Sarnu Untung.

Wiradharma, G. (2020). Dekonstruksi Cerita Rakyat Indonesia Dalam Iklan Televisi Deconstruction Of Folks Stories In Television Advertisement. Universitas Terbuka.

Wiyatmi. (2006). Pengantar Kajian Sastra. Pustaka. 